\title{
FACTORS ASSOCIATED WITH THE DIFFERENCES IN THE SAFETY ATTITUDES QUESTIONNAIRE 2006 SHORT FORM ASSESSMENT OF THE MANAGEMENT OF CROATIAN HOSPITALS
}

\author{
Maša Bulajić ${ }^{1}$, Heri Bezić ${ }^{2}$ \& Davor Plavec ${ }^{3}$ \\ UDC / UDK: 614.253.83:614.21-022.5](497.5) \\ JEL classification / JEL klasifikacija: I11, I18 \\ DOI: https://doi.org/10.22598/pi-be/2017.11.2.9 \\ Preliminary communication / Prethodno priopćenje \\ Received / Primljeno: July 20, 2017 / 20. srpnja 2017. \\ Accepted for publication / Prihvaćeno za tisak: October 20, 2017 / 20. listopada 2017.
}

\begin{abstract}
Summary
Quality, safety and safety culture in healthcare have been recognized as topics of top priority worldwide. However, there is however an unmet need to develop and implement reliable measuring instruments. The measurable part of safety culture is understood as the safety climate and reflects the perception of professionals regarding safety issues at their workplace. It is proven that positive perception of healthcare professionals is related to the reduction of adverse events, adoption of safe behaviors, improved communication, job satisfaction, team work, etc.

Safety Attitudes Questionnaire (SAQ) has been recognized as the only instrument measuring safety culture in a way that correlates with patients' outcomes, as well as with safety climate.

The aim of this study was to identify the factors associated with the differences in the perception of safety climate among the management of Croatian hospitals using the Croatian translation of the SAQ 2006 Short Form Questionnaire assessment.

Maša Bulajić, M.D., M.Sc.Econ., Ph.D. Candidate, Marti Farm LLC, Zagreb, Croatia, E-mail: merkur3005@gmail.com

2 Heri Bezić, Ph.D., Full Professor, University of Rijeka, Faculty of Economics and Business, Rijeka, Croatia, E-mail: heri.bezic@efri.hr

3 Davor Plavec, M.D., Ph.D., Associate Professor, Research Department, Children's Hospital Srebrnjak, Zagreb, Faculty of Medicine, J.J. Strossmayer University of Osijek, Croatia, E-mail: plavec@bolnicasrebrnjak.hr
\end{abstract}


The results of our study show that the safety climate, job satisfaction and working conditions are associated with the size of the hospital (the smaller the hospital, the more satisfied the management).

It seems that smaller hospitals allow for better communication and enable a better safety climate. These results deserve further research to associate these results with patients' outcomes, taking into account the differences in diagnoses, available diagnostics, guidelines, procedures and other parameters.

Key words: attitudes, Croatia, differences, hospital management, SAQ 2006 Short Form.

\section{INTRODUCTION}

Along with progress in all fields of healthcare, development of patients' rights and modifications in stakeholders' attitudes, quality and safety of care are becoming increasingly recognized as topics of top priority. Unsafe practices in healthcare are a public health issue. There is a need to develop strategies to monitor errors, or adverse events, as well as the improvements related to patient safety (Luiz, 2015). The definition of healthcare quality, which is tightly connected to safety, includes also the definition of the safety culture. The safety culture is a set of either individual or group values, perceptions and attitudes which determine the commitment regarding patient safety in healthcare organizations (Nieva, 2003).

A measurable part of the safety culture is understood as safety climate and reflects the professionals' perception of safety issues at their workplace (Sexton, 2006). Positive perception of healthcare professionals regarding safety climate is proven to be related to the reduction of adverse events, adoption of safe behaviors, improved communication, job satisfaction, team work, etc. (Alahmadi, 2010; El-Jardali, 2011). Therefore, several instruments have been developed, aiming to measure the safety culture through the healthcare professionals' perception of the safety climate (Lee, 2010). Identifying which factors are associated with the patient safety climate is a tool of utmost importance, capable of singling out the areas which need improvement. This includes both the level of an individual healthcare professional and the institutional level (Luiz, 2015).

Numerous questionnaires have been developed to conduct quantitative surveys of safety culture in healthcare (Deilkås, 2008). Safety Attitudes Questionnaire (SAQ) is valid and reliable, considered as one of the most sensitive and capable tools for assessing safety attitudes (Colla, 2005). The SAQ has been recognized as the only instrument measuring safety culture in a way that correlates with patients' outcomes (Sexton et al, 2004) as well as with safety climate (Gabrani, 2015).

The aim of this study was to identify the factors associated with the differences in the perception of safety climate among the management of Croatian hospitals using the SAQ 2006 Short Form Questionnaire assessment. 


\section{METHODS}

\subsection{Study design}

The study was designed as a cross-sectional survey of safety attitudes of the management staff of Croatian hospitals. The study was performed between the beginning of September and the end of November 2016, and organized as the on-line survey using the SAQ 2006 Short Form - Croatian version. A cover letter with an invitation to participate in the survey was sent to the general managers of 61 hospitals listed on the Ministry of Health's (MH) publicly disclosed list. The letter explained the aim of the study, terms of participation, including contacts of the principal investigator and the details about the survey. The letter was sent by e-mail together with a web link to SAQ 2006 Short Form Croatian version. The data were collected starting from September $2^{\text {nd }}$, 2016 for 75 days. Each general manager was asked to fill in the questionnaire based on his/her professional point of view and to forward the invitation letter and the link to the questionnaire to the hospital's Quality Manager, Head Nurse and the managers of the somatic clinical areas, respectively.

By opening the link, the participants accessed the questionnaire posted on the Google forms web application. Unless all the questions were answered, with the exception of the name of the hospital, it was not possible to submit the questionnaire. Presuming that the name of the hospital would be frequently omitted, an obligatory question about the size of the hospital was asked in addition, to allow for the planned analysis. One reminder letter was sent to each of the general managers. As the study did not involve patients, the ethics committee's approval was not needed. It was however required in one of the participating hospitals and the study was approved with no objections.

The web-based collecting of answers guaranteed anonymity which had been estimated as important. A no-blame culture has not yet developed to the extent which would guarantee that being recognized would not affect the participant - and consequently the answers. Also, the authors of the SAQ had presumed that web-based data collecting was going to substitute initial personal data collection in the following years (Sexton, 2003).

Asking additional questions regarding other factors which could influence the perception of the safety climate had been agreed with the University of Texas, and the questions were included in the questionnaire right after the list of the translated SAQ 2006 Short Form standard questions. These included questions about the size of the hospital, formal managerial education of the participant, gender, years in service, and the opinion on cost-effectiveness of a possibly implemented quality system in the hospital.

\subsection{Questionnaire}

The SAQ is a self-reported psychometric questionnaire which has become the most commonly used self-reported psychometric questionnaire measuring safety attitudes in front-line workers (Sexton, 2006). The SAQ was developed from the Flight Management Attitudes Questionnaire (FMAQ) (Sexton, 2000) - a human factors survey designed to measure the safety culture in aviation (Helmreich, 1993). 
The SAQ is a reliable tool to measure safety attitudes among the staff of clinical wards, ambulatory clinics, and pharmacies (Deilkås, 2008). It has also been validated in the primary healthcare, e.g. in the Netherlands (Devriendt, 2012) or Slovenia (Klemenc-Ketis, 2017).

The SAQ consists of 30-60 items, measured on a 5-point Likert scale (Sexton, 2006). The SAQ 2006 Short Form is available online (https://med.uth.edu/chqs/surveys/ safety-attitudes-and-safety-climate-questionnaire/). The permission to translate and use the survey for research in Croatia was obtained from the University of Texas, together with the input on how to address relevant additional fields of interest or challenges which were within the scope of the study.

The SAQ was translated into the Croatian language, and validated for its psychometric characteristics. Translation was conducted by using the back-translation technique for the linguistic validation of our translation (Sperber, 2004). The World Health Organization's guidelines for linguistic validation were respected (Process of translation and adaptation of instruments). Some of the professional titles were modified to reflect job descriptions in Croatia. The team consisted of two bi-lingual healthcare professionals, an American and a Canadian, two Croatian healthcare professionals specialized in quality of healthcare, and a psychologist practicing in a hospital who had a broad experience in conducting scientific research and questionnaires, and a professional translation company. The validation study was published elsewhere (Bulajić, 2017) and in this study it was possible to draw conclusions on the internal validity of SAQ, concluding that the Croatian version of the SAQ 2006 Short Form showed satisfactory internal psychometric properties. The correlation between SAQ factors was comparable to that in other SAQ studies.

\subsection{Subjects}

The questionnaire was sent to 61 hospital general managers, which then forwarded the invitation letter and the web-site link to their hospital management staff. There were 105 Croatian hospital managers who answered the questionnaire, out of which 68 were female. There were 36 managers with completed formal education in management/ leadership in healthcare, and 63 without it. According to the number of beds, the hospitals were divided into 4 sizes: $<500$ beds (no. of answers=69), 500-1000 beds (no. of answers=8), 1001-1500 beds (no. of answers $=13$ ), $>1500$ beds (no. of answers $=15$ ). The departments/units included medicine $(n=33)$, board management $(n=27)$, surgery $(n=27)$, psychiatry $(n=11)$, and supportive units - e.g. laboratory, pharmacy $(n=7)$.

There is no available joint data about Croatian hospitals which have implemented ISO or other internationally recognized quality standards, or which are accredited according to some of the recognized international standards. Organizations performing the ISO certification in Croatia only have data about their own clients. Croatian Accreditation Agency (CAA) has an excellent database regarding the implementation of ISO for laboratories, which is in accordance with CAA's responsibilities. The national Agency for Quality and Accreditation in Healthcare and Social Welfare (AQAH) did not have 
any such data. Therefore, the first step was to contact every company performing ISO certification and other recognized certification and/or accreditation companies to gather data. Furthermore, a web search was conducted on the individual hospital level. Finally, the principal investigator performed a survey based on a written correspondence with all hospitals, respectively. The data showed that 16 hospitals implemented ISO at the level of the whole institution (one having also a valid international accreditation certificate), 7 hospitals implemented ISO standards in some of the units, and 23 did not implement ISO at all.

\subsection{Response rate}

We measured the response based on the number of hospitals that participated in the survey. Out of 61 Croatian hospitals we got replies from 49 of them (80\% response rate).

\subsection{Data analysis}

Data analyses were performed using STATISTICA version 12 (StatSoft, Inc., OK, USA). Categorical variables were presented as numbers and proportions (\%). Quantitative variables were presented as mean and standard deviations (SD). Normality of the distributions was tested using Kolmogorov-Smirnov test. Differences for SAQ scores between subgroups were tested using Student's t-test or analysis of variance (ANOVA) using Bonferroni corrections for multiple comparisons. $\mathrm{P}<0.05$ was used as statistically significant for all analyses.

\section{RESULTS}

Mean safety attitudes scores. Mean $( \pm S D)$ SAQ scores for the whole sample and for different subgroups according to subjects' characteristics (level of management, hospital size, years in service, gender, having a formal management education, any type of certification, type of department) are presented in Table 1. An average (SD) total SAQ score was 70.3 (9.5) with the highest score for Job satisfaction (82.0) and the lowest for Stress recognition (62.6) factors. 
Table 1: Mean scores ( \pm standard deviation) of safety factors on 100-point scale of the study population and according to subgroups

\begin{tabular}{|c|c|c|c|c|c|c|c|c|}
\hline Safety factors & $\begin{array}{l}\text { SAQ } \\
\text { Overall }\end{array}$ & $\begin{array}{l}\text { Teamwork } \\
\text { Climate }\end{array}$ & $\begin{array}{l}\text { Safety } \\
\text { Climate }\end{array}$ & $\begin{array}{c}\text { Job } \\
\text { Satisfaction }\end{array}$ & $\begin{array}{c}\text { Stress } \\
\text { Recognition }\end{array}$ & $\begin{array}{c}\text { Perception of } \\
\text { Management } \\
\text { Hospital }\end{array}$ & $\begin{array}{c}\text { Perception of } \\
\text { Management } \\
\text { Unit }\end{array}$ & $\begin{array}{l}\text { Working } \\
\text { Conditions }\end{array}$ \\
\hline $\begin{array}{l}\text { Mean (100 scale) } \\
\pm S D\end{array}$ & $70.3 \pm 9.5$ & $73.2 \pm 11.6$ & $67.9 \pm 12.8$ & $82.0 \pm 14.6$ & $62.6 \pm 22.6$ & $65.8 \pm 15.4$ & $64.2 \pm 14.5$ & $69.6 \pm 21.0$ \\
\hline \multicolumn{9}{|l|}{ Management } \\
\hline $\begin{array}{l}\text { Hosp. management } \\
(\mathrm{n}=24)\end{array}$ & $73.3 \pm 8.8$ & $75.4 \pm 12.6$ & $68.2 \pm 13.9$ & $84.0 \pm 14.3$ & $61.5 \pm 21.9$ & $71.1 \pm 17.4$ & $70.2 \pm 16.6$ & $77.1 \pm 25.8$ \\
\hline $\begin{array}{l}\text { Unit Management } \\
(\mathrm{n}=81)\end{array}$ & $69.5 \pm 9.6$ & $72.6 \pm 11.3$ & $67.8 \pm 12.6$ & $81.4 \pm 14.8$ & $63.0 \pm 22.9$ & $64.2 \pm 14.5$ & $63.3 \pm 15.5$ & $67.4 \pm 19.0$ \\
\hline$p$-value & 0.086 & 0.292 & 0.902 & 0.449 & 0.772 & 0.055 & 0.062 & 0.046 \\
\hline \multicolumn{9}{|l|}{ Hospital size } \\
\hline$<500$ beds $(n=69)$ & $72.0 \pm 8.3$ & $73.9 \pm 10.4$ & $71.0 \pm 10.5$ & $84.7 \pm 13.0$ & $59.1 \pm 23.3$ & $68.4 \pm 14.9$ & $65.9 \pm 14.2$ & $74.6 \pm 17.0$ \\
\hline $\begin{array}{l}500-1000 \text { beds } \\
(n=8)\end{array}$ & $67.3 \pm 12.1$ & $67.4 \pm 16.7$ & $59.6 \pm 15.3$ & $73.1 \pm 19.6$ & $79.7 \pm 11.9$ & $62.5 \pm 15.4$ & $60.7 \pm 15.7$ & $64.6 \pm 26.3$ \\
\hline $\begin{array}{l}1001-1500 \text { beds } \\
(n=13)\end{array}$ & $67.5 \pm 7.2$ & $73.7 \pm 12.0$ & $61.8 \pm 15.0$ & $80.8 \pm 11.3$ & $67.8 \pm 19.9$ & $63.1 \pm 9.9$ & $62.8 \pm 10.3$ & $59.6 \pm 18.3$ \\
\hline$>1500$ beds $(n=15)$ & $66.7 \pm 13.3$ & $72.8 \pm 13.9$ & $63.4 \pm 15.4$ & $75.4 \pm 18.3$ & $65.6 \pm 21.4$ & $57.6 \pm 18.7$ & $59.8 \pm 18.9$ & $57.8 \pm 29.5$ \\
\hline$p$-value & 0.096 & 0.522 & 0.006 & 0.035 & 0.062 & 0.067 & 0.530 & 0.006 \\
\hline \multicolumn{9}{|l|}{ Years in specialty } \\
\hline$<2$ years $(n=12)$ & $63.8 \pm 8.0$ & $60.7 \pm 11.5$ & $60.2 \pm 17.3$ & $79.3 \pm 13.4$ & $52.7 \pm 17.3$ & $61.9 \pm 6.1$ & $61.9 \pm 6.1$ & $60.7 \pm 20.2$ \\
\hline $3-10$ years $(n=16)$ & $66.4 \pm 8.6$ & $67.8 \pm 12.5$ & $65.1 \pm 11.0$ & $74.5 \pm 17.1$ & $65.6 \pm 17.5$ & $58.9 \pm 16.6$ & $58.9 \pm 16.6$ & $63.3 \pm 19.7$ \\
\hline $11-20$ years $(n=31)$ & $69.3 \pm 9.1$ & $74.0 \pm 12.1$ & $67.9 \pm 11.8$ & $80.6 \pm 13.6$ & $64.5 \pm 21.6$ & $63.7 \pm 12.5$ & $63.7 \pm 12.5$ & $65.2 \pm 21.0$ \\
\hline$>21$ years $(n=46)$ & $71.3 \pm 10.1$ & $75.0 \pm 8.9$ & $69.8 \pm 12.3$ & $84.1 \pm 15.0$ & $63.2 \pm 25.8$ & $66.3 \pm 16.1$ & $66.3 \pm 16.1$ & $71.0 \pm 17.1$ \\
\hline$p$-value & 0.177 & 0.006 & 0.258 & 0.299 & 0.651 & 0.504 & 0.504 & 0.380 \\
\hline \multicolumn{9}{|l|}{ Gender } \\
\hline Women $(n=68)$ & $69.7 \pm 10.0$ & $71.9 \pm 12.1$ & $67.0 \pm 13.2$ & $81.4 \pm 14.3$ & $61.3 \pm 22.2$ & $65.5 \pm 16.6$ & $64.2 \pm 15.7$ & $69.4 \pm 21.9$ \\
\hline Men $(n=37)$ & $71.5 \pm 8.6$ & $75.7 \pm 10.3$ & $69.6 \pm 12.1$ & $83.1 \pm 15.3$ & $65.0 \pm 23.2$ & $66.2 \pm 13.1$ & $64.2 \pm 11.8$ & $69.9 \pm 19.6$ \\
\hline p-value & 0.353 & 0.109 & 0.314 & 0.574 & 0.425 & 0.829 & 0.996 & 0.906 \\
\hline \multicolumn{9}{|c|}{ Formal education in management/ healthcare leadership } \\
\hline Yes $(n=36)$ & $69.6 \pm 9.0$ & $70.3 \pm 10.0$ & $67.3 \pm 14.5$ & $81.3 \pm 12.4$ & $62.4 \pm 20.5$ & $67.4 \pm 14.1$ & $65.0 \pm 14.3$ & $68.4 \pm 18.6$ \\
\hline No $(n=63)$ & $70.8 \pm 10.1$ & $74.9 \pm 12.3$ & $68.1 \pm 12.3$ & $82.3 \pm 16.0$ & $63.6 \pm 23.6$ & $64.8 \pm 16.4$ & $63.4 \pm 15.0$ & $71.4 \pm 22.7$ \\
\hline p-value & 0.567 & 0.061 & 0.781 & 0.730 & 0.813 & 0.431 & 0.640 & 0.508 \\
\hline \multicolumn{9}{|c|}{ Any form of certification } \\
\hline Yes $(n=32)$ & $70.7 \pm 9.0$ & $72.6 \pm 10.9$ & $67.6 \pm 14.2$ & $83.8 \pm 13.4$ & $62.2 \pm 20.1$ & $66.6 \pm 16.2$ & $64.9 \pm 14.0$ & $72.1 \pm 21.1$ \\
\hline No $(n=73)$ & $70.2 \pm 9.8$ & $73.5 \pm 12.0$ & $68.1 \pm 12.3$ & $81.3 \pm 15.2$ & $62.8 \pm 23.7$ & $65.4 \pm 15.1$ & $63.9 \pm 14.8$ & $68.5 \pm 21.0$ \\
\hline p-value & 0.782 & 0.712 & 0.865 & 0.423 & 0.905 & 0.712 & 0.765 & 0.416 \\
\hline \multicolumn{9}{|l|}{ Department type } \\
\hline Medicine $(n=33)$ & $70.4 \pm 10.4$ & $74.8 \pm 9.4$ & $67.5 \pm 12.3$ & $84.6 \pm 15.0$ & $62.2 \pm 22.8$ & $64.4 \pm 16.2$ & $62.2 \pm 16.4$ & $72.1 \pm 18.8$ \\
\hline Surgery $(n=27)$ & $69.6 \pm 10.8$ & $73.0 \pm 13.5$ & $69.4 \pm 13.3$ & $80.7 \pm 16.3$ & $62.5 \pm 25.2$ & $66.1 \pm 16.4$ & $65.5 \pm 13.5$ & $65.0 \pm 23.3$ \\
\hline Supportive $(\mathrm{n}=7)$ & $72.1 \pm 8.8$ & $70.6 \pm 16.9$ & $66.1 \pm 11.4$ & $83.6 \pm 13.5$ & $75.9 \pm 16.7$ & $66.1 \pm 15.1$ & $66.1 \pm 15.1$ & $66.7 \pm 22.1$ \\
\hline Psychiatry (n=11) & $71.8 \pm 7.3$ & $75.4 \pm 9.2$ & $70.1 \pm 9.8$ & $82.3 \pm 19.3$ & $64.8 \pm 21.9$ & $66.7 \pm 12.2$ & $65.8 \pm 12.5$ & $72.7 \pm 16.7$ \\
\hline Management $(n=27)$ & $69.9 \pm 8.4$ & $71.4 \pm 11.8$ & $66.5 \pm 14.9$ & $79.7 \pm 10.7$ & $59.0 \pm 21.2$ & $66.8 \pm 15.4$ & $63.9 \pm 14.6$ & $70.1 \pm 23.0$ \\
\hline$p$-value & 0.948 & 0.740 & 0.886 & 0.749 & 0.528 & 0.980 & 0.919 & 0.701 \\
\hline
\end{tabular}

Note: made by authors. 
When subgroups were compared, the overall SAQ score did not reach a significance for any of the subgroup comparisons ( $p>0.08$ for all, Table 1$)$.

A significant difference was found for the Working conditions factor $(\mathrm{p}=0.046)$, and a marginal difference for Perception of hospital $(p=0.055)$ and Unit management $(p=0.067)$ when hospital management and the unit management staff subgroups were compared; higher scores for all the three factors were found in the first subgroup (Table 1).

When subgroup results were compared according to the hospital size, a significant difference was found for factors of Safety climate (highest score for hospitals with $<500$ beds, $\mathrm{p}=0.006$ ), Job satisfaction (highest score for hospitals with $<500$ beds, $\mathrm{p}=0.035$ ), and Working conditions (highest score for hospitals with $<500$ beds, $\mathrm{p}=0.006$ ); with marginal difference for factors of Stress recognition (highest score for hospitals with 500-1000 beds, $\mathrm{p}=0.062)$, and Perception of hospital $(\mathrm{p}=0.055)$ and Unit management $(\mathrm{p}=0.067)$ with highest scores for hospitals with $<500$ beds (Table 1).

There were no significant differences found for any of the SAQ factors for subgroup comparisons according to years in service ( $p>0.15$ for all), gender ( $p>0.10$ for all), formal management education ( $\mathrm{p}>0.05$ for all), any type of hospital quality certification ( $p>0.40$ for all), and type of a department ( $p>0.50$ for all) (Table 1$)$.

\section{DISCUSSION}

\subsection{The Croatian healthcare system}

Health insurance in Croatia consists of mandatory health insurance and voluntary health insurance. The Croatian Health Insurance Fund (CHIF) is the main healthcare insurer and it is only the CHIF that contracts the mandatory insurance. The healthcare system is divided into three levels: primary, secondary and tertiary. There were 61 hospitals registered on the MH's and CHIF's list, out of which 5 university hospital centers, 3 university hospitals, and 5 specialty university hospitals.

There are almost 15.000 physicians in Croatia, out of which 2.699 are employed in secondary care hospitals, and 4.414 in University hospitals and University hospital centers. There are only 27 physicians employed in Croatian private hospitals. In addition, there are 2.397 residency physicians in the tertiary healthcare. There are also approximately 3.600 physicians practicing in the primary healthcare as registered by the Croatian Medical Chamber (Croatian Medical Chamber, 2017).

Croatian healthcare system represents a Bismarck model (Varga, 2012) that has developed as an independent healthcare system after splitting with other ex-Yugoslav countries in the year 1991. Both financial and human resources are scarce. Constant progress in diagnostics and therapy is costly, while patients' needs, expectations and rights have expanded. At the same time, Croatian accession to the EU has resulted in an export of qualified medical staff from Croatia to other countries.

A rising number of national publications targeting quality in healthcare or quality management is evident, including scientific publications (Lazibat, 2007; Lazibat, 2009), professional papers (Žabica, 2014), as well as preliminary reports (Ostojić, 2012). 
Quality in healthcare on the national level is defined by the Act on Quality of Health Care and Social Welfare (Zakon o kvaliteti zdravstvene zaštite i socijalne skrbi), the Health Care Act (Zakon o zdravstvenoj zaštiti), and by the by-law defining mandatory quality indicators (Pravilnik o standardima kvalitete zdravstvene zaštite i načinu njihove primjene). Despite the relevant national strategy on the development of the national healthcare system (Nacionalna strategija razvoja zdravstva 2012-2020) as well as the by-law regarding the national accreditation standards for hospitals (Pravilnik o akreditacijskim standardima za bolničke zdravstvene ustanove), the national accreditation of Croatian hospitals has never been initiated. There is also a constant pressure from the healthcare establishment (MoH and CHIF) to initiate the integration (upscaling) process of the hospitals by their administrative joining. The aim is to produce a more efficient hospital network or hospital system, by reducing the number of hospitals while increasing their size.

There is no data available about the possible external audit scores of each hospital regarding the implementation of the above mentioned mandatory Croatian quality indicators. At the moment, the scores of the mandatory quality indicators are self-reported by quality units or by the hospital staff in charge of quality, without external audit, and they are at the moment partially publicly available for the years 2013-2015 (www.aaz.hr).

Results of the research on a sample of Croatian healthcare institutions at primary, secondary and tertiary levels indicate that there is generally insufficient knowledge and low implementation of the ISO quality management system in the healthcare system (Žabica, 2014).

\subsection{Aim of the study}

The aim of the cross-sectional study was to try to identify the factors associated with the differences in the perception of the safety climate in Croatian hospitals by using the SAQ Short Form 2006 assessment in the sample of the management staff of the Croatian hospitals, and to benchmark the results with other countries. The link between the type of the hospital and the rate and the percentage of adverse events was proven as far back as 25 years ago, when the study results revealed that primary teaching institutions had significantly higher rates of adverse events due to negligence than rural hospitals (Brennan, 1991). However, another study found that the teaching, larger, and more urban hospitals had generally better quality than nonteaching, small, and rural hospitals. Yet, small, nonteaching hospitals narrowed the gap with better quality hospitals in the period between 1981 and 1986 (Keeler, 1992). Downsizing did not affect the quality of care (Brownell, 1999). It has also been proven that smaller and less complex hospital sites perform better than bigger ones in terms of quality of care. This might be due to better communication within the hospital, stronger management, greater integration, higher visibility and accessibility of the environment and therefore perhaps to better flow of information (Pachilova, 2015). It is difficult to draw a reliable conclusion based on the results of the international research, since small hospitals are not necessarily rural, but may be as well both urban and highly specialized. Urban-rural differences as well as the differences related to hospital safety and downsizing were not proven (Brownell, 1999). 
Research also suggests that patient safety error rates increase as hospital size increases, but a limited adjustment for the illness severity may not provide an accurate estimate of the associated risk (Romano, 2003)

\section{CONCLUSION}

The results of our study show that the safety climate, job satisfaction and working conditions are associated with the size of the hospital (the smaller the hospital, the more satisfied the management). There was a marginal association also with stress recognition (hospitals 500-1.000 beds), and the perception of the hospital and unit management (small hospitals up to 500 beds). It seems that smaller hospitals allow for better communication and enable a better safety climate. This might represent a reasonable explanation for the association between the size of the hospital and the mentioned safety climate, job satisfaction and working conditions. Safety climate is a measurable part of safety culture, and it is proven that the job satisfaction and the working conditions influence safety and quality in healthcare. Further research would be needed to associate the size of the hospital to patients' outcomes, taking into account the differences in diagnoses, available diagnostics, guidelines, procedures and other parameters.

\section{REFERENCES:}

1. Alahmadi HA. Assessment of patient safety culture in Saudi Arabian hospitals. Qual Saf Health Care. 2010;9(17):1-5

2. Brennan TA, Hebert LE, Laird NM, et al. (Lawthers A, Thorpe K, Leape LL, Localio AR, Lipsitz SR, Newhouse JP, Weiler PC, Hiatt HH.). Hospital Characteristics Associated With Adverse Events and Substandard Care JAMA. 1991;265(24):3265-3269. doi:10.1001/jama.1991.03460240061028.

3. Brownell MD, Roos NP, Burchill C. Monitoring the impact of hospital downsizing on access to care and quality of care. Med Care. 1999 Jun;37(6 Suppl):JS135-50.

4. Burr M, Sorra J, Nieva VF: Analysis of the Veterans Administration (VA) National Center for Patient Safety (NCPS) FY 2000 Patient Safety Questionnaire. Technical report. Westat: Rockville, MD; 2002. 2002, AHRQ Publication, AHRQ. Ref Type: ReportGoogle Scholar

5. Carthey J, de Leval MR, Reason JT: Institutional resilience in healthcare systems. Qual Saf Health Care. 2001, 10: 29-32. 10.1136/qhc.10.1.29.View ArticleGoogle Scholar

6. "Checklist for Assessing Institutional Resilience" (CAIR). [http://www.ihi.org/IHI/ Topics/PatientSafety/SafetyGeneral/Tools/ChecklistForAssessingInstitutionalResilience.htm]

7. Colla JB, Bracken AC, Kinney LM, Weeks WB: Measuring patient safety climate: a review of surveys. Qual Saf Health Care. 2005, 14: 364-6.

8. Croatian Medical Chamber, e-mail communication, May 22, 2017 
9. Deilkås ET, Hofoss D. Psychometric properties of the Norwegian version of the Safety Attitudes Questionnaire (SAQ), Generic version (Short Form 2006). BMC Health Services Research 2008; 8:191. DOI: 10.1186/1472-6963-8-191

10. Devriendt E, Van den Heede K, Coussement J, Dejaeger E, Surmont K, Heylen D, Schwendimann R, Sexton JB, Wellens NIH, Boonen S, Milisen K. Content validity and internal consistency of the Dutch translation of the Safety Attitudes Questionnaire: an observational study. Int J Nurs Stud. 2012;49:327-37. doi: 10.1016/j. ijnurstu.2011.10.002.

11. El-Jardali F, Dimassi H, Jamal D, Jaafar M, Hemadeh N. Predictors and outcomes of patient safety culture in hospitals. Qual Saf Health Care. 2011;11(45):4-12

12. Gabrani A, Hoxha A, Simaku A, Gabran J. Application of the Safety Attitudes Questionnaire (SAQ) in Albanian hospitals: a cross-sectional study. BMJ Open 2015;5:e006528. doi:10.1136/bmjopen-2014-006528

13. Hamdan M. Measuring safety culture in Palestinian neonatal intensive care units using the Safety Attitudes Questionnaire. J Crit Care. 2013;28:886. doi: 10.1016/j. jcrc.2013.06.002

14. Helmreich RL, Merritt AC, Sherman PJ, Gregorich SE, Wiener EL: The Flight Management Attitudes Questionnaire (FMAQ) NASA/UT/FAA Technical Report. 1993, Austin, TX, The University of Texas, 93-4. Ref Type: Report Google Scholar

15. Hoffmann B, Domańska OM, Müller V, Gerlach FM. Developing a questionnaire to assess the safety climate in general practices (FraSiK): transcultural adaptation--a method report. ZEFQ. 2009;103:521-529.

16. Kaya S, Barsbay S, Karabulut E. The Turkish version of the safety attitudes questionnaire: psychometric properties and baseline data. Qual Saf Health Care. 2010;19:572-7.

17. Keeler EB, Rubenstein LV, Kahn KV, et al. Hospital Characteristics and Quality of Care. JAMA. 1992;268(13):1709-1714. doi:10.1001/jama.1992.03490130097037

18. Klemenc-Ketis Z, Maletic M, Stropnik V, Deilkås ET, Hofoss D, Tschudi Bondevik G.. The safety attitudes questionnaire - ambulatory version: psychometric properties of the Slovenian version for the out-of-hours primary care setting. BMC Health Services Research (2017) 17:36 DOI 10.1186/s12913-016-1972-7

19. Lazibat, T., Burčul, E., Baković, T. (2007). Primjena sustava za upravljanje kvalitetom u hrvatskom zdravstvu, Poslovna izvrsnost/Business Excellence, Vol. 1, No. 2: 31-43.

20. Lazibat, T. (2009). Upravljanje kvalitetom, Zagreb: Znanstvena knjiga

21. Lee WC, Wung HY, Liao HH, Lo CM, Chang FL, Wang PC. Hospital safety culture in Taiwan: a nationwide survey using Chinese version safety attitude questionnaire. BMC Health Serv Res. 2010;10:1-8.

22. Luiz RB, Simões AL, Barichello E, Barbosa MH. Factors associated with the patient safety climate at a teaching hospital. Rev Lat Am Enfermagem. 2015 SepOct;23(5):880-7. 
23. Manchester Patient Safety Framework (MaPSaF). [http://www.npsa.nhs.uk/patientsafety/improvingpatientsafety/humanfactors/mapsaf/]

24. Nacionalna strategija razvoja zdravstva 2012-2020, Vlada RH, rujan 2012. NN $116 / 2012$

25. Nieva VF, Sorra J. Safety culture assessment: a tool for improving patient safety in healthcare organizations. Qual Saf Health Care. 2003;2(Suppl 2):17-23.

26. Nguyen G, Gambashidze N, Ilyas SA, Pascu D. Validation of the safety attitudes questionnaire (short form 2006) in Italian in hospitals in the northeast of Italy. BMC Health Services research (2015), 15:284.

27. Ostojić R, Bilas V, Franc S. Unapređenje kvalitete zdravstvenih sustava zemalja članica Europske Unije i Republike Hrvatske. Poslovna izvrsnost Zagreb 2012; 2: 109-25.

28. Pachilova R, Sailer K. Size and complexity of hospitals matter for quality of care: A spatial classification of NHS buildings. Proceedings of the 10th International Space Syntax Symposium, . 13-17 July 2015, London, UK. Available at: http://www.sss10. bartlett.ucl.ac.uk/wp-content/uploads/2015/07/SSS10_Proceedings_031.pdf

29. Pravilnik o standardima kvalitete zdravstvene zaštite i načinu njihove primjene (Narodne novine 79/2011)

30. Pravilnik o akreditacijskim standardima za bolničke zdravstvene ustanove (Narodne novine, 31/2011)

31. Pronovost P, Sexton B. Assessing safety culture: guidelines and recommendations. Editorial. Qual Saf Health Care 2005;14:231-3.

32. Pronovost PJ, Berenholtz SM, Goeschel CA, Needham DM, Sexton JB, Thompson DA, et al: Creating High Reliability in Health Care Organizations. Health Serv Res. 2006, 41: 1599-1617. 10.1111/j.1475-6773.2006.00567.x.View ArticlePubMedPubMed CentralGoogle Scholar

33. Pronovost PM, Weast BM, Rosenstein BM, Sexton JBP, Holzmueller CGB, Paine LM, et al: Implementing and Validating a Comprehensive Unit-Based Safety Program. Journal of Patient Safety. 2005, 1: 33-40. 10.1097/01209203-200503000-00008.View ArticleGoogle Scholar

34. Romano P S, Geppert J J, Davies S. et al. A national profile of patient safety in U.S. hospitals. Health Affairs. 2003;22(2):154-66.

35. Sexton JB, Helmreich RL, Neilands TB, Rowan K, Vella K, Boyden J. The Safety Attitudes Questionnaire: psychometric properties, benchmarking data, and emerging research. BMC Health Serv Res. 2006;44(6):1-10

36. Sexton JB, Thomas EJ, Helmreich RL, Neilands TB, Rowan K, Vella K, et al: Frontline Assessments of Healthcare Culture: Safety Attitudes Questionnaire Norms and Psychometric properties. Technical report 04-01. 2004, 1-12-12-2007. Ref Type: Report, [http://www.utpatientsafety.org] Google Scholar 
37. Sexton JB, Thomas EJ, Helmreich RL: Error, stress, and teamwork in medicine and aviation: cross sectional surveys. BMJ. 2000, 320: 745-749. 10.1136/bmj.320.7237.745. View ArticlePubMedPubMed CentralGoogle Scholar

38. Sexton JB, Thomas EJ, Grillo SP. The safety attitudes questionnaire (SAQ) Guidelines for administration. The University of Texas Center of Excellence for Patient Safety Research and Practice; Technical Report. Sponsored by the Agency for Healthcare Research and Quality, January 11, 2003

39. Sorra JSNV. Hospital Survey on Patient Safety Culture. Rockville, MD, Agency for Healthcare Research and Quality. 2004, AHRQ Publication 41[04], Ref Type: ReportGoogle Scholar

40. Sperber AD. Translation and validation of study instruments for cross-cultural research. Gastroenterology. 2004, 126: S124-S128.

41. Varga S. Sustav kvalitete u zdravstvu. Dostupno na: http://www.zzjzfbih.ba/wp-content/uploads/2012/11/Varga_Sinisa.pdf

42. Zakon o kvaliteti zdravstvene zaštite i socijalne skrbi (Narodne novine, 124/2011)

43. Zakon o zdravstvenoj zaštiti (Narodne novine, 150/2008, 71/2010, 139/2010, 22/2011, 84/2011, 12/2012, 70/2012, 144/2012.

44. Žabica S., Lazibat T., Dužević I. Implementacija sustava upravljanja kvalitetom na različitim razinama zdravstvene djelatnosti. Poslovna izvrsnost Zagreb, god. Viii (2014) br. 1, 9-24. 


\title{
FAKTORI POVEZANI S RAZLIKAMA U OCJENI UPRAVLJANJA HRVATSKIM BOLNICAMA POMOĆU KRATKOG OBLIKA UPITNIKA SAFETY ATTITUDES QESTIONNAIRE 2006
}

\author{
Maša Bulajić ${ }^{4}$, Heri Bezić ${ }^{5}$ \& Davor Plavec ${ }^{6}$
}

\section{Sažetak}

Kvaliteta i sigurnost zdravstvene zaštite na svjetskoj su razini prepoznati kao teme najviše razine prioriteta. Međutim, i dalje je prisutna nezadovoljena potreba u svezi razvoja i implementacije pouzdanih alata za mjerenje kvalitete i sigurnosti. Onaj diok kvalitete koji s emože mjeriti tumaći se kao ozračje kvalitete, a odražava percepcije zdravstvenih djelatnika u svezi sigurnosnih izazova na njihovim radnim mjestima. Dokazano je da je pozitivna percepcija povezana sa smanjenom pojavnošću neželjenih događaja, prihvaćanjem sigurnog ponašanja, boljom komunikacijom, zadovoljstvom poslom, timskim radom, itd.

Safety Attitudes Questionnaire (SAQ) priznat je kao jedini instrument kojim se kultura sigurnosti mjeri tako da bude u korelaciji s ishodom po pacijenta, kao i s ozračjem sigurnosti.

Cilj istraživanja je identifikacija čimbenika povezanih s razlikama u percepciji ozračja sigurnosti rukovoditelja u hrvatskim bolničkim zdravstvenim ustanovama procjenom pomoću hrvatske inačice SAQ 2006 Short Form upitnika.

Rezultati našeg istraživanja pokazuju da su klima/ozračje sigurnosti, zadovoljstvo poslom i uvjeti rada povezani s veličinom bolničke zdravstvene ustanove (što je manje bolničkih postelja, to su rukovoditelji zadovoljniji.

Čini se da manje bolnice omogućavaju bolju komunikaciju kao i bolje ozračje sigurnosti. Te bi rezultate valjalo potvrditi daljnim istraživanjima kako bi ih se povezalo $s$ ishodima po pacijenta, uzimajući u obzir razlike u dijagnozama, dostupnim dijagnostičkim metodama, smjernicama, postupcima i ostalim parametrima. Form.

Ključne riječi: stavovi, Hrvatska, razlike, upravljanje bolnicama, SAQ 2006 Short

JEL klasifikacija: I11, 118

\footnotetext{
${ }^{4}$ Mr.sc. econ. Maša Bulajić, dr. med., doktorand, Marti Farm LLC, Zagreb, Hrvatska, E-mail: merkur3005@ gmail.com

${ }^{5}$ Dr. sc. Heri Bezić, redoviti profesor, Ekonomski fakultet, Sveučilište u Rijeci, Hrvatska, E-mail: heri. bezić@efri.hr

${ }^{6}$ Dr. sc. Davor Plavec, izvanredni profesor, Znanstveno-istraživački odjel, Dječja bolnica Srebrnjak, Zagreb, Medicinski fakultet, Sveučilište Josipa Jurja Strossmayera u Osijeku, Hrvatska, E-mail: plavec@bolnica-srebrnjak.hr
} 